\section{Is it worth being a doctor? Effective altruism and career choice}

\author{
John Launer
}

If you are a doctor or healthcare professional and have never heard of the effective altruism movement, you may want to take a few moments to learn about it. Effective altruism invites us all to ask the simple question: how can I do most good in my life? ${ }^{1}$ The aim of the social movement that promotes it is to use high-quality evidence and careful reasoning to work out how to help others during one's lifetime, and to encourage people to focus their efforts on the most promising solutions to the world's most urgent problems. Its supporters place an emphasis on addressing problems that are large in scale, relatively neglected and potentially tractable. As examples, they generally cite problems such as poverty in the developing world, the suffering of animals in factory farms and major threats to civilisation such as bioengineering, unrestricted information technology, nuclear war and climate change. They often point out that individual acts of virtue or charity, even if carried out repeatedly over many years, may achieve remarkably little by comparison with acts that are informed by careful analysis. A lifetime spent in the operating theatre or classroom, for example, may have a tiny overall impact on people's lives when compared with the effects of a single large charitable donation to buy insecticidal mosquito nets in countries with malaria. ${ }^{2}$

The idea of effective altruism has its origins in the work of philosophers like Peter Singer $^{3}$ but has had significant traction among young people, especially in relation to how they should go about choosing their careers. One of the movement's main platforms, the website 80000 hours, is aimed at young graduates who want to plan their careers not just based on their individual strengths but on their potential capacity to affect global problems through their achievements. ${ }^{4}$ Setting out from the premise that a young person will be at work for an average of 80000 hours over the course of a lifetime, the site rates different options for spending that time. It presents these in terms of career capital (skills, credentials and connections), along with role impact (opportunities to address global problems by the most effective methods)

Correspondence to Dr John Launer Associate Editor, Postgraduate Medical Journal, London WC1H 9JP, UK; johnlauner@aol.com and the supportive conditions for building these up. One of the strengths of the site is its transparent approach to the reasoning behind the claims and the evidence on which these are based. The mathematical logic that is used to guide career decisions is similar to the logic pointing people towards altruistic actions, including ones that may at first seem counter-intuitive.

\section{THE IMPACT OF BEING A DOCTOR}

Medicine does not come out well from these calculations. In the page on the website that is dedicated to medical careers, its writer Gregory Lewis notes that the direct impact of being a doctor is smaller than conventional wisdom may suggest. Although doctors enjoy widespread public esteem, they do not have a great platform for advocacy. Doctors acquire only modest career capital in terms of the flexibility to move into other jobs relative to the amount of time and money it takes to qualify. It is also hard to change careers within medicine after entering a training programme for a given speciality. Overall, Lewis concludes, a life spent in medicine rates high in job satisfaction and relatively high on earnings, but lower on direct impact and advocacy potential, and particularly low on career capital and ease of competition. Lewis himself appears to have acted on his own deliberations, since he has moved from being a junior doctor in public health to becoming a doctoral student in philosophy at the Future of Humanity Institute at the University of Oxford. ${ }^{5}$

For anyone interested in the long-term impact of their career choices, it seems that there are far better options than medicine. Based on the approach that Lewis has applied to doctors, others have looked at different occupations and come up with a list of those with the greatest potential scope for effective altruism. These include research in areas relevant to global problems; working in government and related policy development; taking up employment within effective non-profit organisations; or applying an unusual strength to a needed niche. 'Otherwise', the website counsels 'earn to give'. In this connection. the 80000 hours website highlights the immense earning potential of quantitative trading in hedge funds using advanced mathematical skills. A young graduate in this field might quickly amass an amount of money that could generate enough interest and capital growth to support a lifetime of informed philanthropy. This option is especially interesting, since a common theme within the movement is to argue that most individuals could do more good by earning large sums of money and donating these to valuable causes than by working in more highly esteemed walks of life such as medicine.

\section{CRITICS OF EFFECTIVE ALTRUISM}

It is not hard to see the attractions of this kind of argument. Nor is it hard to note its shortcomings. Most obviously, there is no fail-safe mechanism to ensure that a pledge to donate generously, made during a phase of youthful idealism, will be sustained in the face of competing demands such as children and family, or when wealth offers alternative attractions such as a bigger home, more expensive cars and exotic vacations. Critics of the movement have drawn attention to its philosophical dependence on utilitarianism (in other words, focussing on mass needs at the expense of individual ones), a stance that has largely become discredited among philosophers. ${ }^{6}$ Others have criticised its 'moralistic, hyperrational' approach $^{7}$; its reliance on what is measurable rather than factors such as justice, equality, fairness and empowerment ${ }^{8}$; and its neglect of the systemic or social causes of most global problems. ${ }^{9}$ It may be no coincidence that much writing in support of effective altruism justifies the career opportunities that, in worldwide terms, are principally available to young white middleclass men with a high level of education who already have privileged access to tremendous earning potential and power.

Writing as someone who has spent many years as an urban general practitioner with what must be exceptionally low career capital, it is hard not to feel somewhat judged by the standards the movement sets. In spite of this, I am happy to have gone into an occupation where there is at least the certainty of doing some good, surrounded by colleagues who collectively contribute to the welfare of the community. This contrasts with the uncertainty of some of the callings recommended by 80000 hours such as politics, where success is doubtful and may enable corruption or poor decision-making that adversely affects millions. In particular, my occupation does not allow me to perpetrate the harms that can be done in some of the other recommended jobs-most notably those falling in the category of 'earn to give'. The amassing of vast wealth by a very small number of individuals, 
sometimes through quantitative trading or other forms of speculation, has in itself arguably led to greater global inequality, undermining of democracy and threats to human survival than any other single cause. ${ }^{1011}$

Having said that, I believe there is a core of sense and decency within effective altruism that we should not lose sight of. As one of its leading critics concedes, 'we should be thinking rigorously, comparatively, and collectively about how individuals can use the money in their possession to improve the world, including (but not only) by increasing individual welfare. ${ }^{8}$ As doctors, we should perhaps be using the same logic to think less highly of ourselves and our career choices and more often about the causes we can support beyond our own daily work.

Twitter John Launer @JohnLauner.
Funding The authors have not declared a specific grant for this research from any funding agency in the public, commercial or not-for-profit sectors.

Competing interests None declared.

Patient consent for publication Not required.

Provenance and peer review Not commissioned; internally peer reviewed.

(C) Author(s) (or their employer(s)) 2020. No commercial re-use. See rights and permissions. Published by BMJ.

\section{Check for updates}

To cite Launer J. Postgrad Med J 2020;96:723-724.

Postgrad Med J 2020;96:723-724.

doi:10.1136/postgradmedj-2020-138936

\section{REFERENCES}

1 Effective altruism. Available https://bit.ly/3laVIVd (accessed 22 Aug 2020)

2 Well G. Against malaria foundation. Available https:// www.givewell.org/charities/amf (accessed 22 Aug 2020)
3 Singer P. The most good you can do: how effective altruism is changing ideas about living ethically. Yale, NJ: Princeton, 2015.

480000 hours. Available https://80000hours.org/ (accessed 22 Aug 2020)

5 Lewis G. Available https://gregoryjlewis.com/

6 Fraser G. It's called effective altruism: but is it really the best way to do good? Guardian. 23 September 2017. Available https://www.theguardian.com/money/belief/ 2017/nov/23/its-called-effective-altruism-but-is-it-reallythe-best-way-to-do-good (accessed 22 Aug 2020)

7 Berger K, Penna RM. The elitist approach of so-called effective altruism. Stanford Social Innovation Review. Available https://ssir.org/articles/entry/the_elitist_phi lanthropy_of_so_called_effective_altruism (accessed 22 Aug 2020)

8 Rubenstein JC. The lessons of effective altruism. Ethics and International Affairs. December 2016 Available https://www.ethicsandinternationalaffairs.org/2016/thelessons-of-effective-altruism/ (accessed 22 Aug 2020)

9 Snow M. Against charity. Available https://www.jaco binmag.com/2015/08/peter-singer-charity-effectivealtruism/ (accessed 22 Aug 2020)

10 Piketty T. Capital in the twenty-first century. Cambridge, MA: Harvard University Press, 2013.

11 Hickel J. The divide: a brief guide to global inequality and its solutions. London: Penguin Random House, 2017. 